\title{
The Tripeptide KdPT Protects from Intestinal Inflammation and Maintains Intestinal Barrier
} Function

\author{
Dominik Bettenworth, ${ }^{*}$ Marion Buyse, ${ }^{\dagger}$ \\ Markus Böhm, ${ }^{\ddagger}$ Rudolf Mennigen, ${ }^{\S}$ \\ Isabel Czorniak, § Klaus Kannengiesser, * \\ Thomas Brzoska, ${ }^{\ddagger}$ Thomas A. Luger, ${ }^{\ddagger}$ \\ Torsten Kucharzik, ${ }^{*}$ Wolfram Domschke, ${ }^{*}$ \\ Christian Maaser, ${ }^{*}$ and Andreas Lügering* \\ From the Departments of Medicine B, Dermatology, ${ }^{*}$ and \\ General Surgery, University of Münster, Münster, Germany; and \\ the Faculté de Pharmacie, ${ }^{\dagger}$ Université Paris-Sud, Paris, France
}

Treatment options for inflammatory bowel disease (IBD) are incompletely helpful, and surgery is often needed. One promising class of future therapeutic agents for IBD is melanocortin-related peptides, which exhibit potent immunomodulatory effects. We investigated KdPT, a tripeptide derivative of the C-terminus of $\alpha$-melanocyte-stimulating hormone, as an anti-inflammatory small molecule in vivo and in vitro. Intestinal inflammation was studied after oral administration of dextran sodium sulfate and in IL-10 gene-deficient mice. The effects of KdPT on key colonic epithelial cell functions were studied in vitro and in vivo by evaluating proliferation, wound healing, transepithelial resistance, and expression of tight junction proteins. Melanin assays were performed to determine the melanotropic effects of KdPT. KdPT-treated animals showed markedly reduced severity of inflammation in both colitis models. In colonic epithelial cells, KdPT increased proliferation, accelerated closure of wounds, and improved transepithelial electrical resistance after stimulation with interferon- $\gamma /$ tumor necrosis factor- $\alpha$. Moreover, treatment with KdPT also prevented the loss of tight junction protein expression and improved barrier function in vivo. KdPT acted independently of IL-1 receptor type I in vivo and did not affect melanogenesis in vitro. KdPT is capable of attenuating the course of experimental colitis in different models and maintains epithelial cell function. Furthermore, KdPT does not induce pigmentation, emphasizing the potential of this small molecule for the future treatment of IBD. (Am J Pathol 2011, 179:1230-1242; DOI: 10.1016/j.ajpath.2011.05.013)
Inflammatory bowel disease (IBD) is an umbrella term comprising the two main entities Crohn's disease and ulcerative colitis. In the United States, IBD is among the five most prevalent gastrointestinal diseases, costing approximately $\$ 1.7$ billion annually. An estimated 1.4 million Americans were diagnosed as having IBD in 2005. ${ }^{1}$ Commonly, IBD shows chronic, uncontrolled inflammation of the mucosa. ${ }^{2}$ Although great research efforts have been made regarding the pathogenetic understanding of IBD, its etiology is still not completely understood. However, a breakdown of epithelial barrier function seems to play a crucial role.

Most therapeutic strategies for IBD target immunosuppression to inhibit mucosal inflammation. These strategies include mesalazine, budesonide, prednisolone, azathioprine, methotrexate, and antibodies toward tumor necrosis factor- $\alpha$ (TNF- $\alpha){ }^{3}$ Despite these therapeutic options, $70 \%$ of patients with Crohn's disease will need surgery at least once in their lifetime. In contrast, ulcerative colitis can be cured by resection of the colon and rectum. However, note that the risk of complications (eg, pouchitis) rises up to $50 \% .^{4,5}$ In addition, many of the previously mentioned agents have adverse effects, such as bone marrow suppression, liver toxicity, and increased risk of infections or osteoporosis. Therefore, novel therapeutic approaches are needed.

$\mathrm{KdPT}$ is a tripeptide that is structurally similar to the three C-terminal amino acids of $\alpha$-melanocyte-stimulat-

Supported by an interdisciplinary grant from the Deutsche Forschungsgemeinschaft (MA 2247/3-1 to M.Bö. and C.M.) and by a grant from Wolff Arzneimittel, Bielefeld, Germany (A.L.).

Accepted for publication May 23, 2011.

C.M. and A.L. contributed equally to this work.

CME Disclosure: The authors did not disclose any relevant financial relationships.

Supplemental material for this article can be found at http://ajp. amjpathol.org or at doi: 10.1016/j.ajpath.2011.05.013.

Current address of T.K. and C.M., Department of Internal Medicine and Gastroenterology, Klinikum Lueneburg, Lueneburg, Germany.

Address reprint requests to Christian Maaser, M.D., Department of Internal Medicine and Gastroenterology, Klinikum Lueneburg, Boegelstrasse 1, D-21339 Lueneburg, Germany. E-mail: christian.maaser@ klinikum-lueneburg.de. 
ing hormone $(\alpha-\mathrm{MSH})$ and KPV, which are thought to mediate many of the anti-inflammatory effects of $\alpha-\mathrm{MSH}^{6}{ }^{6}$ $\alpha-\mathrm{MSH}$ belongs to the family of melanocortins, which elicit their effects via melanocortin receptors (MC-Rs). ${ }^{7,8}$ We previously showed that MC-1R has a crucial role in intestinal inflammation. ${ }^{9}$ Among the intracellular target molecules that mediate the anti-inflammatory effects of $\alpha-\mathrm{MSH}$ is the transcription factor NF- $\kappa \mathrm{B}$, whose activation by proinflammatory cytokines, such as IL- $1 \beta$ and TNF- $\alpha$, is attenuated. ${ }^{10,11}$ Similarly, a substantial body of data demonstrates that KPV exerts anti-inflammatory effects. ${ }^{12}$ We recently showed that KPV has salutary effects in experimental colitis and acts partially independently of MC-1R. ${ }^{13}$ These data were confirmed by others, and it was also proposed that the reduction of intestinal inflammation by KPV is mediated through an $\mathrm{H}^{+}$-coupled oligopeptide transporter, called PepT1, located at the apical membrane of intestinal epithelial cells. ${ }^{14}$

In contrast to $\alpha$-MSH and KPV, few data exist on KdPT. In 1988, Ferreira et $\mathrm{al}^{15}$ demonstrated that KdPT suppresses IL-1 $\beta$-induced pain in the hind paws of the rat. Because the L-enantiomer of KdPT is homologous to the amino acids 193 to 195 of IL- $1 \beta$, an antagonistic interaction between KdPT and IL-1 $\beta$ was suggested. ${ }^{16,17}$ Regarding the anti-inflammatory potential of KdPT, no further studies have been conducted to our knowledge. Preliminary data from our group, however, suggest that KdPT suppresses experimentally induced contact dermatitis in mice more effectively than does KPV. ${ }^{18}$ Herein, we provide evidence that KdPT has potent concentrationdependent anti-inflammatory effects in two different models of experimental colitis. In addition, we demonstrate various anti-inflammatory effects on colonic epithelial cells in vitro and in vivo, suggesting that KdPT might be beneficial for the treatment of intestinal inflammatory disorders by stabilizing intestinal barrier function.

\section{Materials and Methods}

\section{Animals}

C57BL/6 WT mice were purchased from Charles River Laboratories, Sulzfeld, Germany. In initial experiments, no major sex-specific differences could be detected in the course of colitis, so the experiments described herein were conducted using female mice for practical reasons only. The animals were 6 to 8 weeks old at the beginning of the experiments.

Homologous IL-10 gene-deficient mice (strain name: B6.129P2- $/ / 10^{\operatorname{tm} 1 \mathrm{Cgn} / J}$ ) were purchased from The Jackson Laboratory (Bar Harbor, ME). In the experiments described herein, female mice were 8 to 9 weeks old when they received treatment with piroxicam, a nonsteroidal anti-inflammatory drug. Signaling-deficient MC-1R mice (MC1Re/e) on a C57BL/6 background were a gift from Roger D. Cone (Vollum Institute and the Center for Weight Regulation and Associated Disorders, Oregon Health and Science University, Portland, OR). Owing to a single nucleotide deletion in position 549, the MC-1R protein from this animal is out of frame, resulting in pre- mature termination of the protein after the fourth transmembrane domain. No major sex-specific differences were reported in the course of colitis or its severity, ${ }^{19}$ so the experiments described herein were performed using female mice for practical reasons only. B6.12957$\| 111^{t m} 1 / m x / \mathrm{J}$ mice and corresponding control animals were purchased from The Jackson Laboratory. The experiments described herein were performed with 10- to 12-week-old female mice.

All the animals were kept under pathogen-free conditions at $24^{\circ} \mathrm{C}$ with a controlled 12-hour day-night cycle and had free access to a standard diet and drinking water. The animal studies were approved by the local animal subjects committee at the University of Münster (permit G92/2002).

\section{DSS-Induced Colitis}

Dextran sodium sulfate (DSS)-induced colitis was accomplished as described previously. ${ }^{9,13}$ In brief, mice were given 3\% DSS (ICN Biomedicals Inc., Eschwege, Germany) in drinking water for 5 days, and disease activity was monitored daily by body weight measurement. Afterward, the mice received regular drinking water again to monitor the improvement in inflammation. PBS-diluted KdPT (Bachem Americas Inc., Torrance, CA) was given daily by i.p. injection, by oral gavage, or locally by rectal application in various concentrations until the end of the experiment. Control mice received PBS only.

At the end of the experiment, the mice were sacrificed and the colons removed. The colons were opened, embedded in Tissue-Tek O.C.T. (Sukura Finetek Europe, Zoeterwoude, The Netherlands), and kept frozen at $-80^{\circ} \mathrm{C}$ until further use. Sections $(5 \mu \mathrm{m})$ were stained with $\mathrm{H} \& \mathrm{E}$ and were analyzed by two blinded investigators (D.B. and C.M.).

\section{Induction of Colitis in $\mathrm{L}-10^{-/-}$Mice}

The targeted disruption of the IL-10 gene in mice leads to spontaneous development of chronic enterocolitis. ${ }^{20,21}$ To aggravate the developing colitis, piroxicam was given on days 1 to 7 (60 mg/250 g of food) and on days 15 to 22 (80 mg/250 g of food). ${ }^{22}$ Piroxicam was mixed with rodent chow. PBS-diluted KdPT was given daily by oral administration beginning on day 0 before the start of piroxicam administration until the end of the experiment. Control mice received PBS only. Disease activity was monitored daily by body weight measurement. At the end of the experiment, mice were sacrificed and the colons removed. Colons were opened, embedded in O.C.T., and kept frozen at $-80^{\circ} \mathrm{C}$ until further use. Sections (5 $\mu \mathrm{m})$ were stained with $\mathrm{H} \& \mathrm{E}$ and were analyzed by two blinded investigators (D.B. and A.L.).

\section{Detection of IL-1 $1 \beta$ Expression}

In distal colon samples, IL-1 $\beta$ was measured by real-time RT-PCR. RNA was isolated by TRIzol (Invitrogen, Carlsbad, CA), followed by DNA digestion with DNase (Stratagene, La Jolla, CA) and reverse transcription using $1 \mu \mathrm{L}$ 
of SuperScript II reverse transcriptase (Invitrogen) per sample. Amplification of IL- $1 \beta$ was performed with 40 cycles and the sense 5'-CAGGATGAGGACATGAGCACC-3' and antisense 5'-CTCTGCAGACTCAAACTCCAC-3' primers, generating a 455-bp product. The amplification cycles consisted of 1 minute of denaturation at $95^{\circ} \mathrm{C}, 1$ minute of annealing at $60^{\circ} \mathrm{C}$, and 1 minute of extension at $72^{\circ} \mathrm{C}$. $\beta$-Actin was amplified with 35 cycles and the sense 5'-CAAAGACCTGTACGCCAACAC-3' and antisense 5'CATACTCCT GCTTGCTGATCC-3' primers. The quantitative detection of IL- $1 \beta$ was performed by delta $C_{T}$ values using the $A B I$ PRISM 7000 sequence detection system (Applied Biosystems, Foster City, CA).

\section{Ki-67 Immunohistochemical Analysis}

Five-micrometer colonic tissue sections were blocked (1\% rabbit serum in PBS) for 1 hour and incubated overnight at $4^{\circ} \mathrm{C}$ with a diluted $(1: 100)$ primary rat anti-mouse Ki-67 monoclonal antibody (TEC-3; Dako, Copenhagen, Denmark). After washing with PBS, the sections were incubated for 30 minutes with biotinylated anti-rat IgG antibody diluted 1:100 in 1\% rabbit serum for 1 hour at room temperature, rinsed, and reacted with fluorescein isothiocyanate-conjugated streptavidin (Vector Laboratories, Burlingame, CA) for 60 minutes. DAPI was used for nuclear counterstaining. To assess proliferation activity, the number of Ki-67-positive cells per total crypt epithelial cells was counted. The Ki-67 labeling index was defined as the percentage of Ki-67-positive cells per crypt. $^{23}$ All the sections were analyzed by two blinded investigators (D.B. and A.L.).

\section{Cell Culture}

Normal human melanocytes (PromoCell, Heidelberg, Germany) were maintained in MGM-M2 plus all supplements (Cascade Biologics, Portland, OR). HT-29 (passage 21), Caco-2, and T84 cells (passages 22 to 28) were cultured in Dulbecco's modified Eagle's medium (Gibco-Invitrogen, Cergy-Pontoise, France) supplemented with $20 \%$ fetal bovine serum (Gibco-Invitrogen), $1 \%$ nonessential amino acids, and $1 \%$ penicillin/streptomycin in a $5 \% \mathrm{CO}_{2}, 95 \%$ humidity environment at $37^{\circ} \mathrm{C}$.

Cells were seeded on Costar Transwell membrane inserts with 0.4- $\mu \mathrm{m}$ pores (Corning, New York, NY) at a density of $5 \times 10^{4} \mathrm{cells} / \mathrm{cm}^{2}$ for transport measurements or on 24-well plastic culture dishes for uptake experiments. Three days after seeding, the medium was changed daily. The experiments were conducted on day 17 of culture if not specified otherwise.

\section{In Vitro KdPT Uptake Studies}

On the day of the uptake experiment, the medium was removed and monolayers were washed three times with a Krebs' modified buffer at $\mathrm{pH} 5,6$, or 7.4. Cells were then incubated for 5 minutes with $0.5 \mathrm{~mL}$ of a $20 \mu \mathrm{mol} / \mathrm{L}$ Gly-Sar solution containing $0.4 \mu \mathrm{Ci} / \mathrm{mL}^{3} \mathrm{H}-\mathrm{Gly}$-Sar (Isobio, Fleurus, Belgium) (specific activity, $0.5 \mathrm{Ci} / \mathrm{mmol}$ ) or a $20 \mu \mathrm{mol} / \mathrm{L} \mathrm{KdPT}$ solution containing $0.4 \mu \mathrm{Ci} /{ }^{3} \mathrm{H}-\mathrm{KdPT}$
(Isobio) as a tracer with or without Gly-Gly (SigmaAldrich, St Louis, MO), KPdT, and KPV (Bachem) or GlySar (Sigma-Aldrich), Gly-Pro (Sigma-Aldrich) as potential competitors. At the end of incubation, cells were washed three times in ice-cold buffer. Radioactivity was determined by liquid scintillation counting, and the results are expressed as disintegrations per minute per square centimeter per 5 minutes or as disintegrations per minute per gram per milliliter.

\section{Transport Experiments}

On the day of the transport experiment, the medium was removed and apical and basolateral compartments were washed three times with a Krebs' modified buffer at $\mathrm{pH} 6$ or 7.4 , respectively, at $37^{\circ} \mathrm{C}$ or $4^{\circ} \mathrm{C}$. Transepithelial electrical resistance (TER) was measured in each well using an EVOM epithelial voltohmmeter (World Precision Instruments, Saratosa, FL). No monolayer was used if the TER value was $<150 \Omega / \mathrm{cm}^{2}$. Cells were then incubated for 15 minutes with gentle circular shaking. After incubation, the apical buffer was removed and filled with $0.5 \mathrm{~mL}$ of 20 $\mu \mathrm{mol} / \mathrm{L} \mathrm{KdPT}$ solution containing $0.4 \mu \mathrm{Ci} / \mathrm{mL}{ }^{3} \mathrm{H}-\mathrm{KdPT}$ (Isobio) (specific activity, $0.4 \mathrm{Ci} / \mathrm{mmol}$ ) as a tracer with or without $50 \mathrm{mmol} / \mathrm{L}$ of Gly-Gly (Sigma-Aldrich), KPdT (Bachem), or Gly-Sar (Sigma-Aldrich) or Gly-Pro (SigmaAldrich) as potential competitors. Basolateral compartments were sampled at $0,5,10,15,20,25$, and 30 minutes, and ${ }^{3} \mathrm{H}-\mathrm{KdPT}$ concentration was calculated after measuring radioactivity using a $\beta$-counter (Beckman LS 6000 TA liquid scintillation counter; Beckman Coulter, Fullerton, $C A)$. Apparent permeability $\left(P_{\mathrm{app}}\right)$ was used to describe Gly-Sar or KdPT transport across the monolayer following the equation $P_{a p p}=(d C / d t) .(V / C O A)$, where $V$ is the volume of the basolateral compartment, $\mathrm{CO}$ is the initial drug concentration in the apical compartment chamber, $A$ is the surface of the membrane, and $\mathrm{dC} / \mathrm{dt}$ is the permeability rate (plot slope of the concentration in the receiver chamber versus time).

\section{Everted Intestinal Rings Uptake Assays}

Uptake of $\left({ }^{3} \mathrm{H}\right) \mathrm{KdPT}$ or $\left({ }^{3} \mathrm{H}\right) \mathrm{Gly}$-Sar by everted intestinal rings was determined as previously described. ${ }^{24}$ Briefly, animals were anesthetized, and the entire intestine from the duodenum to the colon was quickly excised, rinsed with ice-cold saline solution, everted, and cut into $1-\mathrm{cm}$ pieces. Rings from the duodenum, the jejunum, the ileum, and the colon were incubated for 5 minutes in MES buffer, $\mathrm{pH} 6$, in a shaking water bath at $37^{\circ} \mathrm{C}$, with continuous bubbling with $95 \%$ oxygen. The buffer contained $1 \mu \mathrm{Ci} /$ $\left({ }^{3} \mathrm{H}\right) \mathrm{KdPT} \pm 170 \mathrm{mmol} / \mathrm{L}$ of a mixture of Gly-Gly and Gly-Pro(94:6) or $0.5 \mu \mathrm{Ci} / \mathrm{mL}\left({ }^{3} \mathrm{H}\right)$ Gly-Sar $\pm 170 \mathrm{mmol} / \mathrm{L}$ of a mixture of Gly-Gly and Gly-Pro. After the incubation period, rings were washed three times in ice-cold saline solution and weighed. Radioactivity incorporated into the tissue was determined by liquid scintillation counting after solubilization of the tissues in Soluene (Beckman) overnight at $56^{\circ} \mathrm{C}$. Results are expressed as disintegration per minute per gram $\left(\mathrm{dpm} \mathrm{g}^{-1}\right)$ tissue wet weight. 


\section{Mechanically Induced Cell Layer Wound Assays}

In vitro wound assays were performed using a modified method first described by Burk. ${ }^{25}$ Confluent monolayers of Caco-2 cells grown in 60-mm plastic dishes (Falcon; Becton Dickinson, Mount View, CA) were cut using a razor blade. Two wounds (20 to $25 \mathrm{~mm}$ ) at a distance of $10 \mathrm{~mm}$ were established per dish. Cells were washed twice with PBS to remove residual cell debris. Wounded monolayers were then cultured for 24 hours in fresh serum-deprived medium ( $0.1 \%$ fetal bovine serum) with or without KdPT at various concentrations. After methylene blue staining, the number of cells across the wound border was expressed as the mean number of cells that crossed the wound border in a standardized wound area. Wound areas were standardized by taking photographs at 200-fold magnification using a DM LB microscope with a DC 300F Leica camera (Leica Microsystems Schweiz, Heerbrugg, Switzerland). Experiments were performed in triplicate, and several wound areas per plate were used to quantify migration.

\section{MTS Cell Proliferation/Viability Assay}

The CellTiter $96 \mathrm{AQ}_{\text {ueous }}$ nonradioactive cell proliferation assay (Promega, Mannheim, Germany) was used to determine the number of viable cells in culture. Caco-2 cells were seeded into 96-well microplates containing routine growth medium. The plates were preincubated with or without KdPT at concentrations from $10^{-5}$ to $10^{-11} \mathrm{~mol} / \mathrm{L}$ for 24 hours at $37^{\circ} \mathrm{C}$. MTS reagent was added, and cell cultures were incubated at $37^{\circ} \mathrm{C}$ for 4 hours. Absorbance was recorded at $490 \mathrm{~nm}$.

\section{TER Assays after Cytokine Stimulation}

T84 epithelial cells (American Type Culture Collection, Manassas, VA) were grown in 1:1 Dulbecco's modified Eagle's medium and Ham's F-12 medium supplemented with $15 \mathrm{mmol} / \mathrm{L}$ HEPES (pH 7.5), $14 \mathrm{mmol} / \mathrm{L} \mathrm{NaHCO}_{3}$, antibiotics, and $6 \%$ NCS. $^{26}$ Cells were then seeded on collagen-coated, permeable polycarbonate filters (5- $\mu \mathrm{m}$ pore size) with surface areas of $5 \mathrm{~cm}^{2}$ (Costar, Cambridge, MA), as described previously. TNF- $\alpha(10 \mathrm{ng} / \mathrm{mL}$; Genzyme, Cambridge, MA) and interferon- $\gamma($ IFN- $\gamma)(100$ $\mathrm{U} / \mathrm{mL}$; Genentech, San Francisco, CA) were added basolaterally to monolayers. T84 cells were co-stimulated with $\mathrm{KdPT}$ at various concentrations. All the monolayers were checked for high TER every 24 hours using an epithelial voltohmmeter.

\section{Immunofluorescence of Tight Junction Proteins}

On day 10 after the start of DSS application and on day 31 after the start of KdPT application in IL-10-deficient mice, frozen sections (5 $\mu \mathrm{m})$ with histologically intact epithelium were collected on coated slides, dried overnight, fixed in acetone for 3 minutes, and dried for 30 minutes. Fixed sections were washed in PBS and blocked in PBS with $2 \%$ bovine serum albumin (SigmaAldrich) for 30 minutes. Slides were incubated with the primary antibody for 30 to 60 minutes at room temperature (rabbit anti-ZO-1, rabbit anti-occludin, rabbit anticlaudin-1, rabbit anti-claudin-3, and rabbit anti-claudin-5; Zytomed Systems GmbH, Berlin, Germany). Slides were washed three times with PBS and were incubated for 1 hour with the appropriate secondary antibody [Alexa Fluor 488-conjugated goat anti-rabbit Ig (Invitrogen)]. Slides were washed, and nuclei were counterstained with DAPI (Sigma-Aldrich). Stained sections were mounted using ProLong Gold antifade (Invitrogen). Samples were imaged using a Nikon epifluorescence microscope (Eclipse E800; Nikon Instruments, Melville, NY) connected to a Nikon FDX-35 camera (Nikon Instruments).

\section{In Vivo Permeability to Evans Blue}

An isoflurane- $\mathrm{N}_{2} \mathrm{O}$ anesthesia laparotomy was performed, and a small polyethylene tube (G22) was inserted into the proximal colon ascendens (immediately
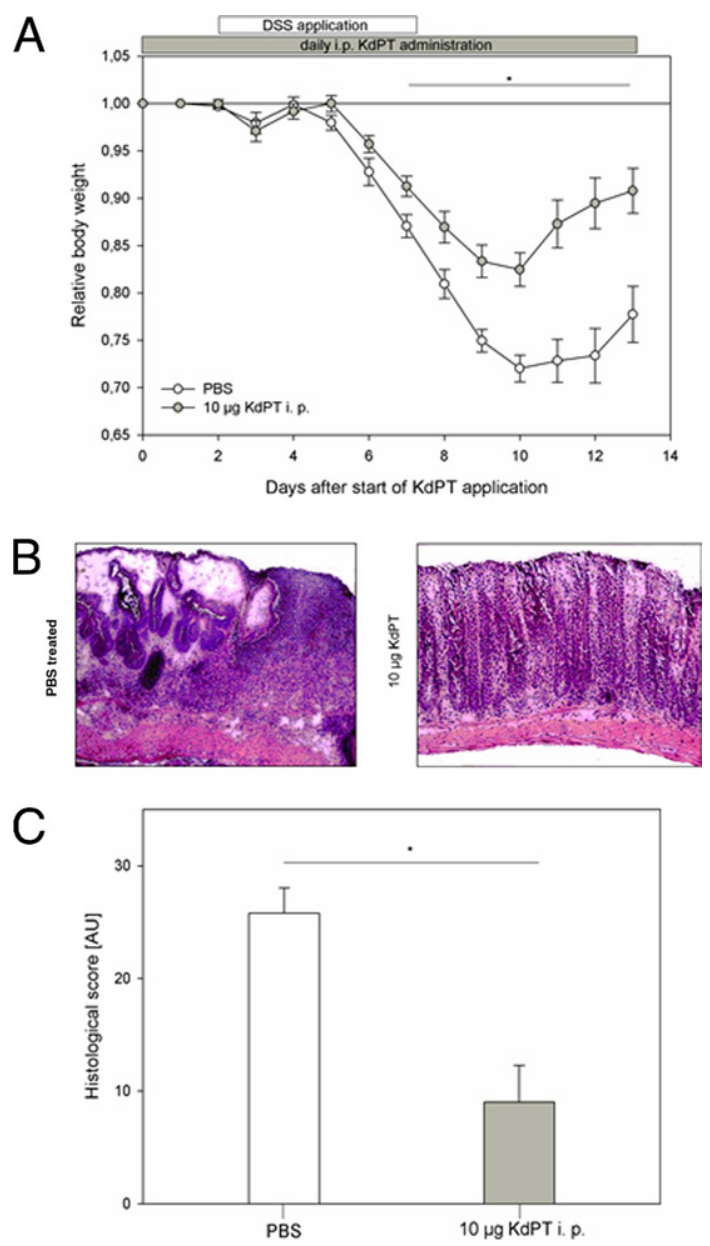

Figure 1. KdPT ameliorates DSS-induced colitis. C57BL/6 WT mice received $3 \%$ DSS in their drinking water for 5 days, and inflammation was monitored by daily measurement of individual weights. A: From day 2 onward, one group was treated with $10 \mu \mathrm{g}$ of KdPT i.p. daily, and control animals received an equivalent volume of PBS i.p. Data are mean \pm SE; $n=5$ for each group. ${ }^{*} P<0.05$. B: Representative histologic images of control mice and KdPTtreated animals 13 days after induction of colitis. C: Histologic scores of colonic tissue according to the method of Dieleman et $\mathrm{al}^{29}$ of control mice and KdPT-treated animals 13 days after induction of colitis. Data are mean \pm SE; $n=5$ for each group. ${ }^{*} P<0.003$. 
adjacent to the cecum) and secured by a ligature. Via this tube, the colon was gently flushed until all stool was rinsed out. Evans blue (Sigma-Aldrich) was instilled into the colon and was left in place for 15 minutes. The colon was rinsed with PBS until the perianal washout was clear. The animals were euthanized, and the colon was rapidly taken out. It was rinsed again, followed by $1 \mathrm{~mL}$ of 6 $\mathrm{mmol} / \mathrm{L} \mathrm{N}$-acetylcysteine to eliminate dye sticking to the colonic mucus. The colon was opened and rinsed once more with PBS. The whole colon was placed in $2 \mathrm{~mL}$ of $\mathrm{N}$, $\mathrm{N}$-dimethylformamide for 12 hours to extract the Evans blue dye. Dye concentration in the supernatant was measured spectrophotometrically at $610 \mathrm{~nm}$ and was given as extinction per gram colonic tissue. ${ }^{27,28}$

\section{Melanin Assays}

Normal human melanocytes ( 1 to $1.5 \times 10^{5}$ cells) were seeded into $3.5-\mathrm{cm}$ tissue culture plates. After deprivation from bovine pituitary extract for 48 hours, cells were treated with $\mathrm{KdPT}$ at $10^{-6}$ to $10^{-10} \mathrm{~mol} / \mathrm{L}$. As a positive control, bovine pituitary extract was used. After 5 days, cells were detached by trypsinization and centrifuged. Cell pellets were dissolved in $1 \mathrm{~N}$ of $\mathrm{NaOH}$, and melanin concentration was determined by measuring the OD at $405 \mathrm{~nm}$ in relation to a standard curve generated by synthetic melanin (Sigma-Aldrich).

\section{Statistical Analysis}

For statistical analysis of body weight, mean \pm SE body weights were determined each day. To test the results for significance, a two-way analysis of variance test was applied where suitable. A $P<0.05$ was considered significant.

\section{Results}

\section{KdPT Attenuates DSS-Induced Colitis}

In the first set of experiments, the effect of i.p.-administered KdPT was investigated. For evaluation of the pro- phylactic potency, mice received $10 \mu \mathrm{g}$ of KdPT i.p. beginning 2 days before DSS application for 13 days until the end of the experiment, and control animals received PBS. At the beginning of the experiment, the mean \pm SE body weight of all the animals was $20.4 \pm 0.53 \mathrm{~g}$. Progressive weight loss was observed in both groups starting on day 6 after KdPT application (Figure 1A). KdPTtreated animals, however, lost significantly less body weight (mean \pm SE maximum: $17.5 \% \pm 1.78 \%$ ) compared with PBS-treated mice (mean \pm SE maximum: $27.9 \% \pm 1.41 \% ; P<0.05$ ). All the animals survived DSS treatment. Histologic examination on day 13 after starting KdPT application showed less epithelial disintegration and denudation, ulceration, edema, and muscular thickening and fewer immune cell infiltrates and lymphatic follicles in KdPT-treated mice than in controls (Figure 1B). Histologic scoring according to the method of Dieleman et al ${ }^{29}$ confirmed a significantly higher mean \pm SE score in control mice $(25.8 \pm 2.25 \mathrm{AU})$ versus $\mathrm{KdPT}$-treated animals $(9.0 \pm 3.29 \mathrm{AU} ; P<0.003$; Figure $1 \mathrm{C})$.

Next, the effect of KdPT on colonic inflammation was tested in a therapeutic setting and at various concentrations. Mice received $0.5,5,10,25$, or $50 \mu \mathrm{g}$ of KdPT i.p. daily from day 2 after starting DSS for 9 days until the end of the experiment, and control animals received PBS (Figure $2 \mathrm{~A}$ ). Animals treated with 5,10 , or $25 \mu \mathrm{g}$ of $\mathrm{KdPT}$ i.p. daily showed a significantly reduced loss of body weight and recovered significantly earlier from colitis than did controls. For example, the mean \pm SE body weight of all animals treated with $10 \mu \mathrm{g}$ of $\mathrm{KdPT}$ i.p. daily was $17.1 \pm 0.46 \mathrm{~g}$ at the beginning of the experiment. Body weight dropped in both groups starting on day 6 after DSS application. KdPT-treated animals again exhibited significantly less reduction in body weight (mean \pm SE maximum: $11.6 \% \pm 3.41 \%)$ compared with that of PBStreated mice (mean \pm SE maximum: $22.6 \% \pm 2.88 \% ; P<$ $0.05)$. None of the treated animals died, and histologic analysis was performed on sacrificed mice on day 10 after DSS. In accordance with the reduced body weight drop, KdPT-treated mice had less epithelial disintegration with ulcerations, edema, and muscular thickening; fewer immune cell infiltrates and lymphatic follicles; and
A

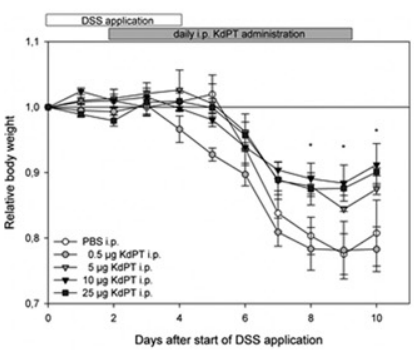

B

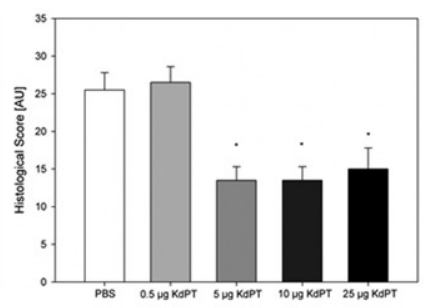

C

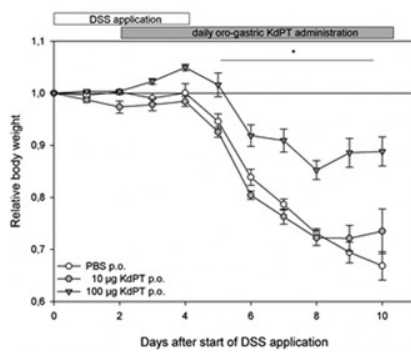

$\mathrm{D}$

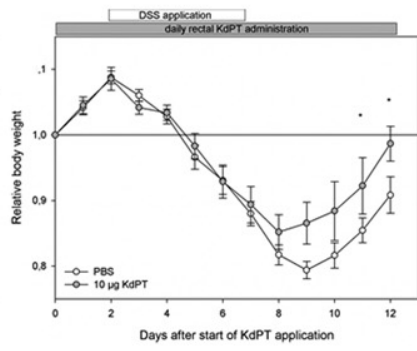

Figure 2. Effect of KdPT at various concentrations after i.p. administration and after oral and rectal application in DSS-induced colitis. C57BL/6 mice received various amounts of KdPT by daily i.p. injections starting 2 days after induction of DSS colitis. Inflammation was monitored by individual body weight. A: Overal weight loss was significantly less intense in mice receiving 5 and $25 \mu \mathrm{g}$ of KdPT daily, whereas lower concentrations were not effective. Data are mean \pm SE; $n=5$ for each group. ${ }^{*} P<0.05$. B: Histologic scores of colonic tissue according to the method of Dieleman et al ${ }^{29}$ in control mice and animals treated with different doses of KdPT i.p. Note that KdPT doses of $<5 \mu \mathrm{g}$ of KdPT per day did not ameliorate DSS-induced colitis. Data are mean \pm SE; $n=5$ to 7 for each group. ${ }^{*} P<0.05$. C: Impact of oral administration of KdPT on DSS-induced colitis. C57BL/6 mice received 10 or $100 \mu \mathrm{g}$ of KdPT by oral gavage 2 days after starting DSS treatment. Note that only $100 \mu \mathrm{g}$ was effective. Data are mean \pm SE; $n=5$ for each group. ${ }^{*} P<0.05$. D: Rectal application of KdPT ( $10 \mu \mathrm{g}$ ) improves DSS-induced colitis. Data are mean $\pm \mathrm{SE} ; n=5$ for each group. ${ }^{*} P<0.05$. 


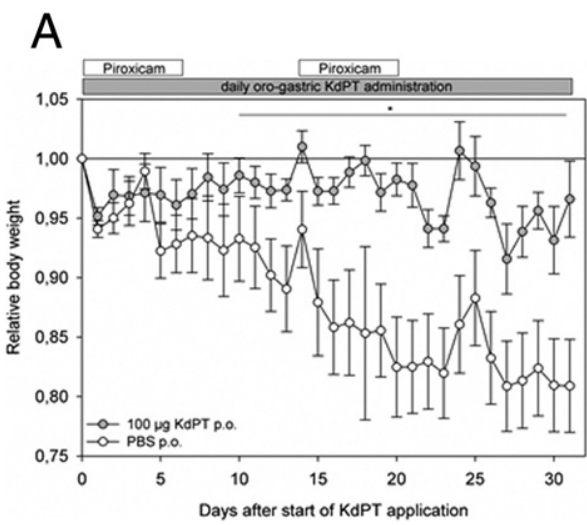

\section{$\mathrm{B}$}

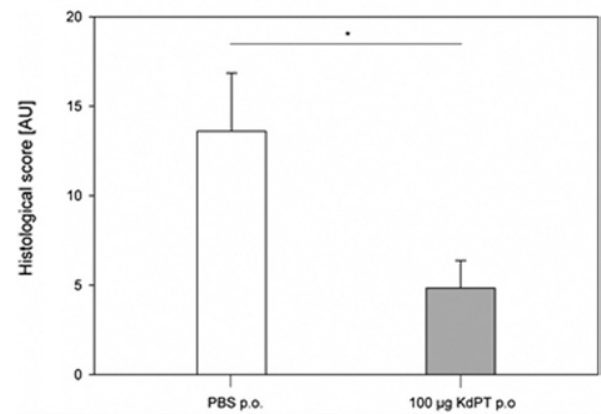

Figure 3. KdPT attenuates colitis in nonsteroidal anti-inflammatory drugtreated IL-10-deficient mice. A: IL-10-deficient mice orally received $100 \mu \mathrm{g}$ of KdPT per day beginning on day 0 after administration of piroxicam until the end of the experiment on day 31, and control animals received PBS. Note the progressive weight loss in PBS-treated animals compared with KdPTtreated mice. Data are mean $\pm \mathrm{SE} ; n=7$ mice. ${ }^{*} P<0.05$. B: Histologic scores of colonic tissue in PBS- and KdPT-treated animals after 31 days. Data are mean $\pm \mathrm{SE} ; n=7$ per group. ${ }^{*} P<0.01$.

smaller areas of epithelial denudation (mean \pm SE score: $13.5 \pm 1.8 \mathrm{AU}$ ) than did PBS controls (mean \pm SE score: $25.5 \pm 2.3 \mathrm{AU}$; Figure 2B). Moreover, IL-1 $\beta$ mRNA expression was reduced approximately threefold in mucosal samples of KdPT-treated mice $(P<0.01$; data not shown). Treatment with $0.5 \mu \mathrm{g}$ of KdPT i.p. daily did not attenuate the course of DSS-induced colitis, whereas the group treated with $50 \mu \mathrm{g}$ of KdPT i.p. daily even developed significantly higher loss of body weight than did control animals (data not shown).

In another set of experiments, we investigated whether administration of KdPT by oral gavage might have antiinflammatory effects on DSS-induced colitis (Figure 2C). For this purpose, mice were treated with 10, 100, and 500 $\mu \mathrm{g}$ of KdPT p.o. daily beginning on day 2 after the start of DSS application. Treatment with $10 \mu \mathrm{g}$ of KdPT did not alter the course of colitis. In contrast, mice treated with $100 \mu \mathrm{g}$ of KdPT lost significantly less body weight than did controls $(P<0.05)$. Treatment with higher dosages of $\mathrm{KdPT}$, eg, $500 \mu \mathrm{g}$ daily, aggravated the course of colitis, as indicated by an increased loss of body weight (data not shown).

Finally, we checked whether local intraluminal application of KdPT had anti-inflammatory effects in DSS-induced colitis (Figure 2D). Mice received $10 \mu \mathrm{g}$ of KdPT rectally by gavage needle on day 2 before starting DSS until day 12. The initial mean \pm SE body weight of all the animals was $18.5 \pm 0.37 \mathrm{~g}$, and it dropped in $\mathrm{KdPT}$ - and PBS-treated mice. KdPT-treated mice lost a mean \pm SE maximum of $14.8 \% \pm 2.62 \%$ of their initial weight, whereas controls lost $20.7 \% \pm 1.31 \%$ at most $(P<0.05$; Figure 2D). In accordance with the weight data, histologic scoring of colonic tissue of sacrificed mice (day 12) revealed significantly less inflammation in KdPT-treated animals (mean $\pm \mathrm{SE}: 2.4 \pm 1.83 \mathrm{AU}$ ) than in controls (mean \pm SE: $20.8 \pm 2.8 \mathrm{AU} ; P<0.04$ ).

Taken together, these findings highlight a significant anti-inflammatory action of KdPT in experimentally induced colitis. When applied i.p., doses of 10 to $25 \mu \mathrm{g}$ of $\mathrm{KdPT}$ per day are sufficient to attenuate the course of DSS-induced colitis (Figure 2A). To elicit beneficial effects of KdPT on DSS-induced colitis by oral administration, higher doses, ie, beginning at $100 \mu \mathrm{g}$, are needed.

\section{KdPT Attenuates Colitis in Nonsteroidal Anti-Inflammatory Drug-Treated \\ IL-10-Deficient Mice}

To extend the previous findings, we used another model of experimental colitis. IL-10-deficient mice are known to develop a spontaneous colitis that can be aggravated by oral administration of a nonsteroidal drug, such as piroxicam. ${ }^{22}$ Accordingly, IL-10-deficient mice received an effective oral dose of KdPT (100 $\mu \mathrm{g}$ daily) beginning on day 0 after administration of piroxicam until the end of the experiment on day 31, and control animals received PBS. Immediately after starting the first piroxicam treatment, all the placebo-treated animals showed progressive weight loss up to a mean \pm SE of $19.9 \% \pm 3.8 \%$ on day 27 . However, the KdPT-treated group exhibited a significantly less pronounced loss of body weight of a mean \pm SE of $8.4 \% \pm 2.9 \%(P<0.05)$ on day 27 , confirming the protective effect of KdPT regarding intestinal inflammation (Figure 3A).

Histologic examination on day 31 after starting KdPT application revealed less severe inflammation with reduced involvement of the submucosa and a lower num-
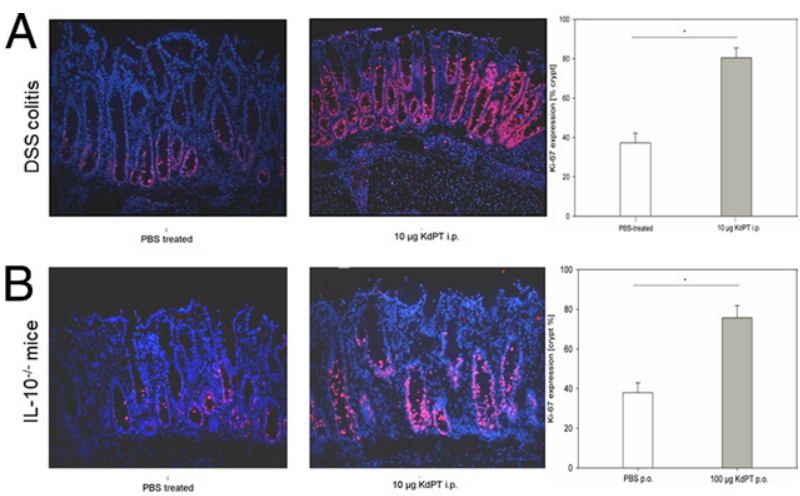

Figure 4. Induction of cell proliferation after stimulation with KdPT in DSS-treated and IL- $10^{-/-}$mice. Immunohistochemical analysis of the cell proliferation marker Ki-67 in colonic tissue of PBS-treated mice and KdPTtreated animals 13 days after induction of DSS colitis (A) and in IL-10 ${ }^{-/-}$mice 31 days after piroxicam treatment $(\mathbf{B})$. Data are mean \pm SE; $n=5$ for each group. ${ }^{*} P<0.05$. 
A

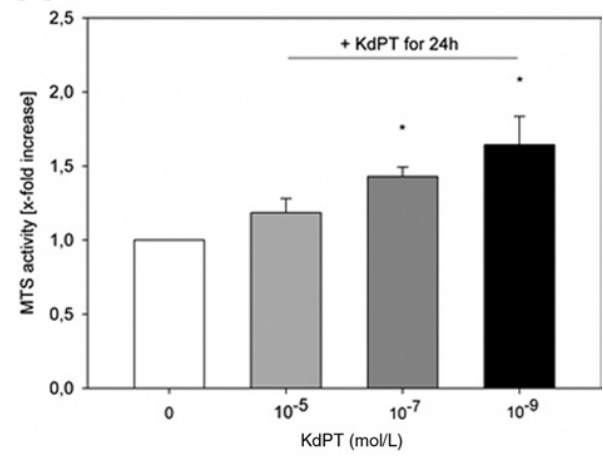

B

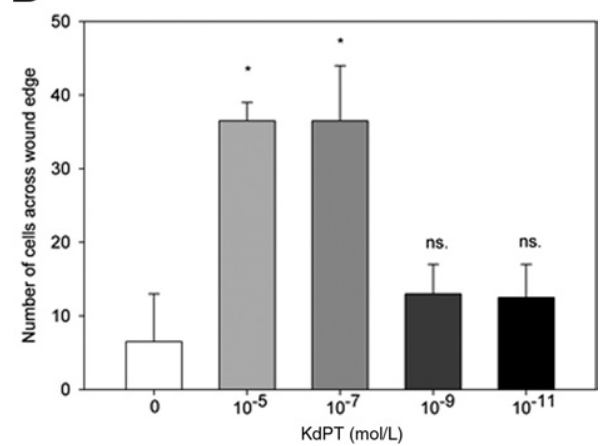

proliferation and viability in vitro: stimulation of Caco-2 cells with $10^{-7}$ and $10^{-9} \mathrm{~mol} / \mathrm{L} \mathrm{KdPT}$ for 24 hours increased MTS activity by approximately mean \pm SE $43 \% \pm 6.3 \%$ and $64 \% \pm 19 \%$, respectively $(P<0.05$; Figure $5 A)$.

To further characterize the effect of KdPT on epithelial cell injury, we analyzed the effect of KdPT on mechanically induced cell monolayer wounds. After setting a defined wound to a monolayer of Caco-2 cells, KdPT at $10^{-5}$ and $10^{-7} \mathrm{~mol} / \mathrm{L}$ significantly accelerated wound healing within 24 hours compared with control $\left({ }^{\star} P<0.05\right.$; Figure 5B).

\section{KdPT Stabilizes Tight Junction Proteins in Vitro and in Vivo}

Because the proinflammatory cytokines IFN- $\gamma$ and TNF- $\alpha$ have been reported to break down the epithelial barrier function by affecting tight junction protein localization, we next analyzed the effects of KdPT on IFN- $\gamma / \mathrm{TNF}-\alpha$ treated T84 epithelial monolayers. ${ }^{26}$ Confluent T84 monolayers grown on permeable supports were incubated with $\mathrm{KdPT}$ after IFN- $\gamma / \mathrm{TNF}-\alpha$ stimulation, and TER was mea-
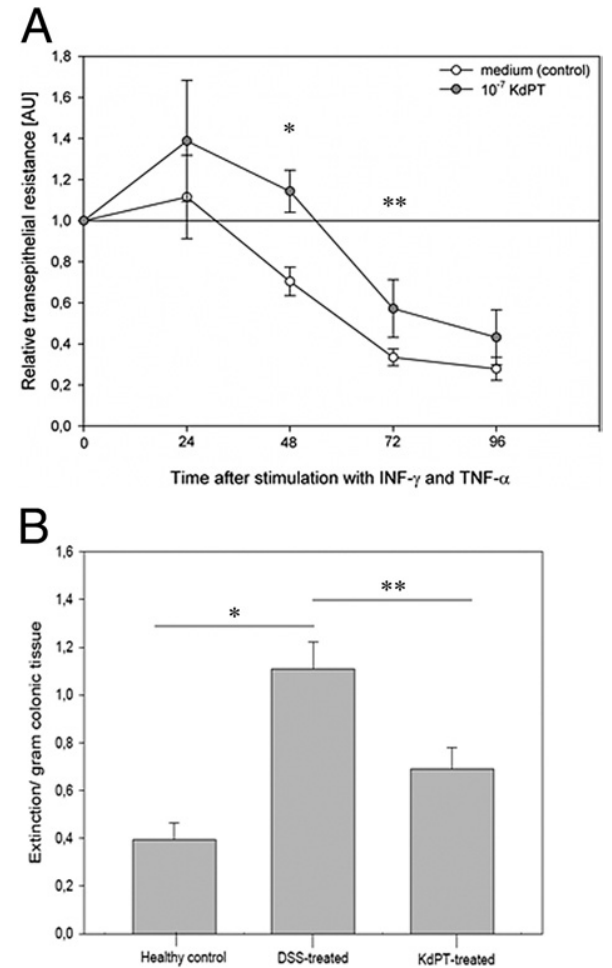

Figure 6. KdPT increases TER in colonic epithelial cells. A: TER in epithelial cells (T84) decreases after stimulation with IFN- $\gamma /$ TNF- $\alpha$. After 48 hours, mean \pm SE TER was $70.4 \% \pm 7 \%$, and co-stimulation with KdPT significantly increased TER $(110 \% \pm 10 \%)$. Data are mean \pm SE; $n=6 .{ }^{*} P=0.01,48$ hours; ${ }^{* *} P=0.04,72$ hours. B: KdPT prevents increased colonic epithelia permeability in acute DSS-induced colitis. To assess the permeability of the colonic epithelium, the colon was perfused with Evans blue in vivo for 15 minutes, and its uptake into the mucosa was quantified spectrophotometrically. Compared with controls (mean \pm SE extinction/gram colon tissue: $0.39 \pm 0.07)$, there was a massively increased uptake of Evans blue in the DSS-treated group (mean \pm SE extinction/gram colon tissue: $1.11 \pm 0.13$ ), indicating a disrupted epithelial barrier. Concomitant treatment with KdPT completely prevented this increase in permeability (mean \pm SE: $0.69 \pm 0.09$ ). Values are given as mean $\pm \mathrm{SE} ; n=5$ per group. ${ }^{*} P=0.026$, healthy control versus DSS-treated; ${ }^{* *} P=0.48$, DSS-treated versus KdPT-treated. 
sured every 24 hours for 96 hours. At all time points tested, KdPT-treated T84 cells maintained significantly better resistance after IFN- $\gamma / \mathrm{TNF}-\alpha$ stimulation, suggesting that KdPT also targets tight junction protein localization in epithelial cells (Figure 6A).

To test whether KdPT is also functionally capable of maintaining intestinal barrier function after DSS challenge in vivo, we measured Evans blue uptake into the colonic mucosa (Figure 6B). Compared with controls, a strong and significant increase of Evans blue uptake into the colonic mucosa of DSS-treated mice was observed. This increase of Evans blue uptake could be significantly reduced by concomitant oral administration of KdPT $(P<$ 0.05), demonstrating that KdPT therapy ameliorates the leakiness of the colonic epithelium.

To further investigate the effect of KdPT treatment on tight junction protein expression in vivo, we examined the effect of the tripeptide on protein expression and organization of candidate tight junction proteins by immunofluorescence microscopy after DSS treatment and in IL-10deficient mice. In the colon of control mice, the tight junction proteins ZO-1, occludin, claudin-1, claudin-3, and claudin-5 were strongly expressed at the epithelial apical cell-cell contacts, at the surface, and in the crypts (Figure 7). For claudin-5, a typical additional staining of the basolateral plasma membrane was observed. After treatment with DSS, a substantial loss of ZO-1, occludin, and claudin-5 was detected, as reported earlier. ${ }^{31}$ This loss was manifested by a reduction in staining intensity and complete discontinuations in membrane staining in multiple areas. This was most dramatically observed for occludin and ZO-1 at the apical membrane. In contrast, in the colon of KdPT-treated animals, the expression of
ZO-1, occludin, and claudin-3 was essentially maintained at the epithelial surface and in the crypts. Only a few areas showed reduced expression of these proteins. However, no effects on tight junction protein expression could be observed in the early phase after the induction of colitis (days 0 to 2; data not shown). In addition, staining for ZO-1, occludin, claudin-1, claudin-3, and claudin-5 in KdPT-treated IL-10 gene-deficient mice indicates that the expression of these tight junction proteins was maintained.

\section{KdPT Attenuates Colitis in IL-1 Receptor-Deficient Mice}

Owing to the sequence similarity between KdPT and amino acids 193 to 195 of human IL- $1 \beta$, KdPT may act as an $\mathrm{IL}-1$ antagonist. ${ }^{15}$ Indeed, we recently found potent attenuating effects of KdPT on IL- $1 \beta$-induced IL- 6 and IL-8 expression in human sebocytes, presumably by interaction between the small peptides and the $\mathrm{IL}-1$ receptor (IL-1R). ${ }^{32}$ In addition, recent findings revealed increased susceptibility of DSS-induced colitis in mice with deficient IL-1R type I. ${ }^{33}$ Therefore, we tested the effect of $\mathrm{KdPT}$ in DSS-induced colitis of IL-1R type I-deficient mice. IL-1R-deficient mice received an effective oral dose of KdPT (100 $\mu \mathrm{g} / \mathrm{d}$ ) beginning on day 2 after administration of DSS until the end of the experiment on day 9, and control animals received PBS. Progressive weight loss was observed in both groups starting on day 6 after DSS application (Figure 8A). KdPT-treated animals, however, again lost significantly less body weight (mean \pm SE maximum: $7.4 \% \pm 2.2 \%$ ) compared with that ob-
Healthy control

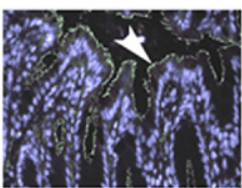

ZO-1
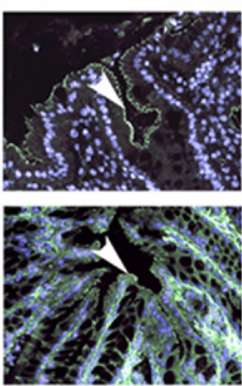

$\mathrm{Cl}-1$
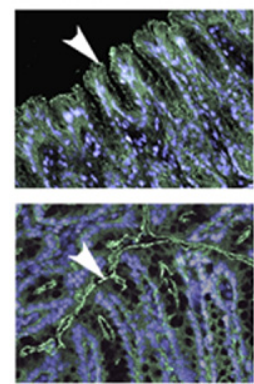

DSS
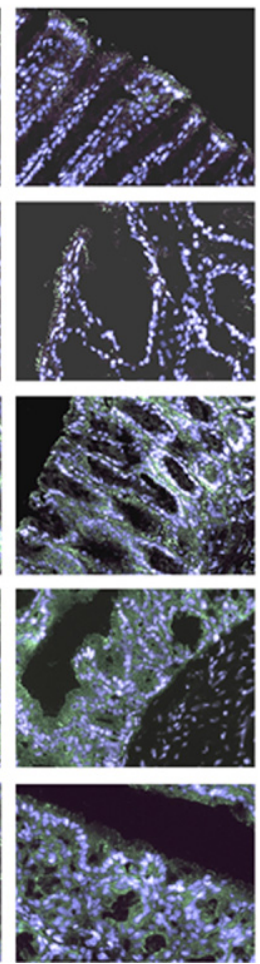

DSS + KdPT
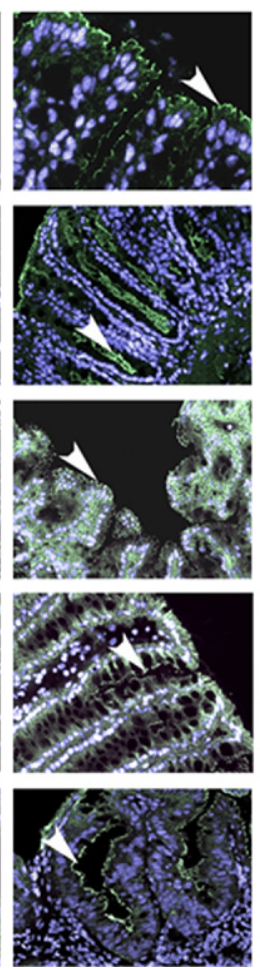

IL-10 colitis + KdPT
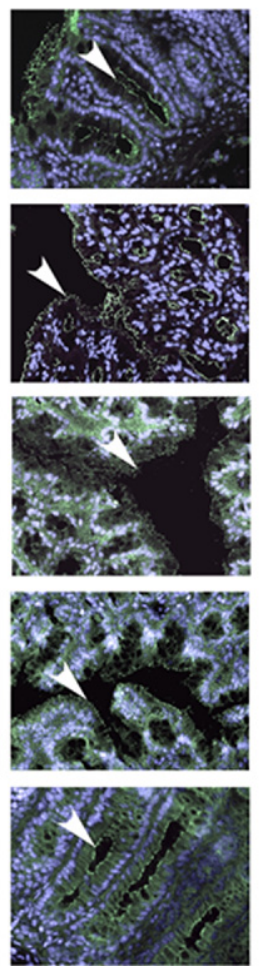

Figure 7. KdPT maintains tight junction protein localization in colonic epithelium in situ. The tight junction proteins ZO-1, occludin (Occ) claudin-1 (Cl-1), Cl-3, and Cl-5 were stained after DSS challenge and in IL-10-deficient mice. In control animals, $\mathrm{ZO}-1$, Occ, $\mathrm{Cl}-1$, and $\mathrm{Cl}-3$ are mostly localized at the apical membrane and are displayed by an intense apical fluorescence band; $\mathrm{Cl}-5$ was additionally expressed at the basolateral membrane. In IL-10 gene-deficien mice (day 31 after the start of KdPT application) and after treatment with DSS (day 10 after the start of DSS application), the apical staining of $\mathrm{ZO}-1$, Occ, $\mathrm{Cl}-1, \mathrm{Cl}-3$, and $\mathrm{Cl}-5$ is strongly reduced, whereas in KdPT-treated animals, the junction proteins stain markedly longer. Images are representative of five animals in each group. Arrowheads represent the positive membrane staining of indicated tight junction proteins. 
A

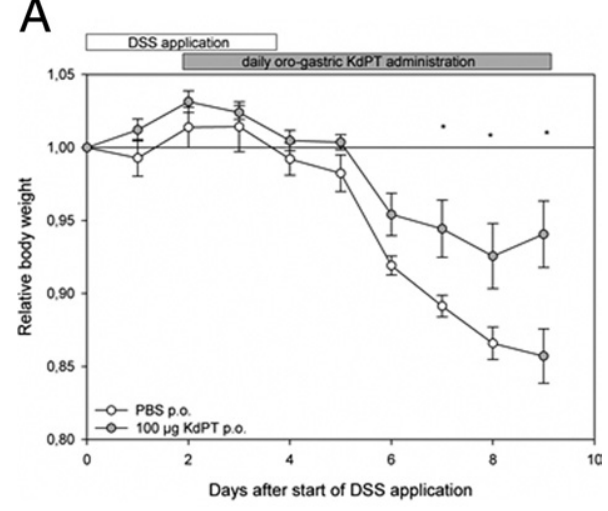

B

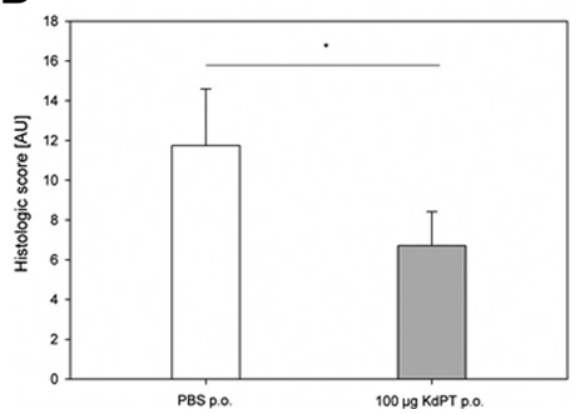

Figure 8. KdPT ameliorates DSS-induced colitis in IL-1R type I-deficient mice. A: IL-1R type I-deficient mice received 3\% DSS in their drinking water for 5 days, and inflammation was monitored by daily measurement of individual weights. From day 2 after the start of DSS application, one group was treated with $100 \mu \mathrm{g}$ of KdPT p.o. daily, and control animals received an equivalent volume of PBS i.p. Data are mean \pm SE; $n=7$ for each group. ${ }^{*} P<0.05$. B: Histologic scores of colonic tissue according to the method of Dieleman et $\mathrm{al}^{29}$ of control mice and KdPT-treated animals 9 days after induction of colitis. Data are mean $\pm \mathrm{SE} ; n=7$ for each group. ${ }^{*} P<0.05$

served in PBS-treated mice (mean \pm SE maximum: $14.3 \% \pm 1.9 \% ; P<0.05)$. All the animals survived DSS treatment. On day 9 after DSS application, histologic examination according to the method of Dieleman et $\mathrm{al}^{29}$ confirmed a significantly higher score in control mice (mean $\pm \mathrm{SE}: 11.8 \pm 2.8 \mathrm{AU}$ ) than in KdPT-treated animals (mean $\pm \mathrm{SE}: 6.7 \pm 1.7 \mathrm{AU} ; P<0.05$; Figure $8 \mathrm{~B}$ ).

\section{Uptake of KdPT Is Transporter Mediated}

Previous data have shown that the effect of KPV, another anti-inflammatory tripeptide sharing $100 \%$ identity with the last three amino acids of the C-terminal domain of $\alpha$-MSH, involves the oligopeptide transporter PepT1. ${ }^{14}$ To analyze the characteristics of KdPT transport into epithelial cells, we first studied the impact of extracellular $\mathrm{pH}$ on KdPT absorption in Caco-2 cells. This human colonic cell line expresses PepT1. ${ }^{34} \mathrm{KdPT}$ uptake increased with the proton gradient, and it was lowest when the proton gradient was abolished (intracellular and extracellular $\mathrm{pH}$ fixed at 7.4). Second, KdPT transport was shown to be energy dependent because it was drastically reduced at $4^{\circ} \mathrm{C}$. Finally, $\mathrm{KdPT}$ transport was saturable, suggesting that KdPT uptake is transporter mediated (Figure 9).

However, in Caco-2 cells, KdPT was absorbed only at very low efficacy compared with Gly-Sar, a classical and specific PepT1 substrate (mean \pm SE: $561 \pm 29$ versus $7946 \pm 336 \mathrm{dpm} / \mathrm{cm}^{2} / 5$ minutes). In HT-29 cells lacking PepT1, ${ }^{14}$ Gly-Sar uptake was drastically reduced, whereas KdPT uptake was decreased by only approximately 50\% compared with $\mathrm{KdPT}$ uptake in Caco- 2 cells (mean \pm SE: $561 \pm 29$ versus $286 \pm 47$ $\mathrm{dpm} / \mathrm{cm}^{2} / 5$ minutes; Figure 10A). PepT1 protein expression in Caco-2 cells increases with confluence and cell differentiation, as does Gly-Sar uptake (day 4: $469 \pm 66$ $\mathrm{dpm} / \mathrm{g} / \mathrm{mL}$ versus day 17: $2194 \pm 92 \mathrm{dpm} / \mathrm{g} / \mathrm{mL})$. However, KdPT uptake actually decreased with increasing cell differentiation in Caco-2 cells (day 4: $417 \pm 98 \mathrm{dpm} /$ $\mathrm{g} / \mathrm{mL}$ versus day 17: $155 \pm 8 \mathrm{dpm} / \mathrm{g} / \mathrm{mL}$; Figure 10B). If KdPT were a substrate of PepT1, it would competitively inhibit Gly-Sar uptake. We, therefore, examined the inhibitory effect of increased concentrations of KdPT, KPV, or Gly-Pro, a well-characterized dipeptide PepT1 substrate, on PepT1-mediated uptake of Gly-Sar (Figure 10C). As already described, Gly-Pro induced a dose-dependent inhibition of Gly-Sar uptake (40\% inhibition at $0.1 \mathrm{mmol} / \mathrm{L}$, $80 \%$ at $1 \mathrm{mmol} / \mathrm{L}$, and $92 \%$ at $10 \mathrm{mmol} / \mathrm{L})$. On the other hand, KPV decreased Gly-Sar uptake only at a high concentration (92\% inhibition at $10 \mathrm{mmol} / \mathrm{L})$ without any effect at lower concentrations. KdPT (10 mmol/L) induced a $60 \%$ maximum decrease in Gly-Sar uptake. Consequently, at comparable concentrations, KdPT seemed

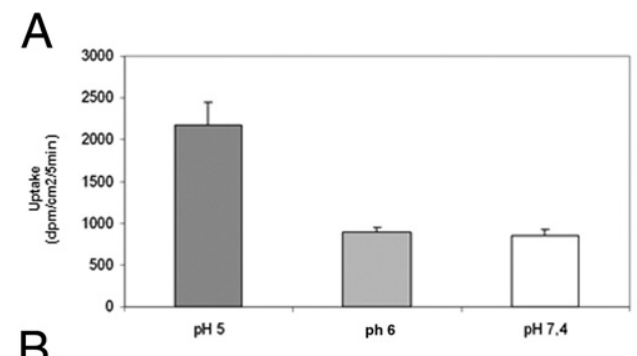

B
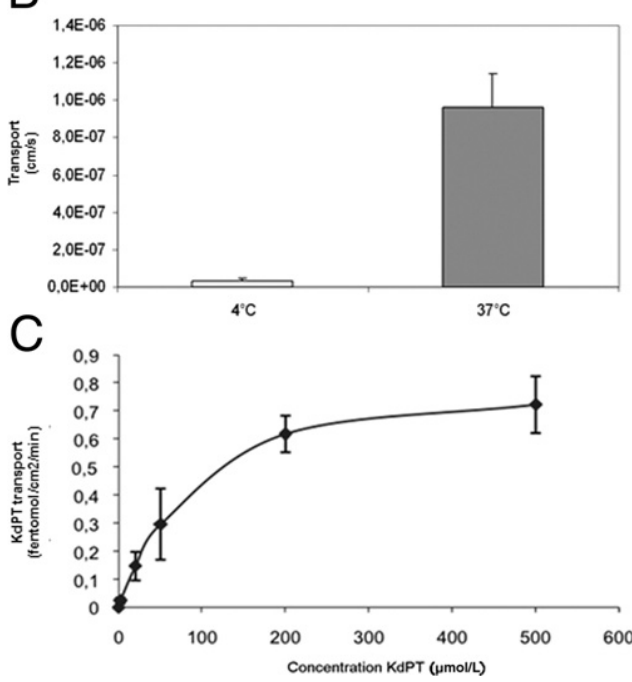

Figure 9. Saturable uptake of KdPT is dependent on $\mathrm{pH}$ and energy. Uptake or transport of KdPT by intestinal epithelial cells was measured in vitro in Caco-2 cells. With increased proton gradient, uptake of KdPT was significantly enhanced approximately threefold $(P<0.05)(\mathbf{A})$, whereas a temperature of $4^{\circ} \mathrm{C}$ almost completely abolished its transport (B). C: Saturable uptake of KdPT by Caco-2 cells was shown by increasing the concentration of $\mathrm{KdPT}$ up to $500 \mu \mathrm{mol} / \mathrm{L}$. Data are mean $\pm \mathrm{SE}$. All the experiments were performed in triplicate. 
A

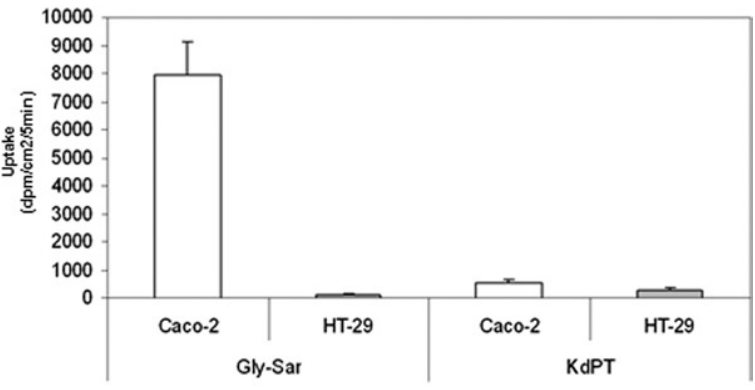

B

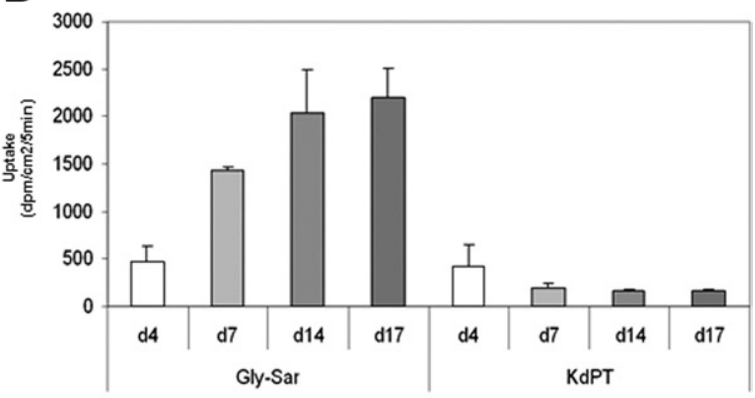

C

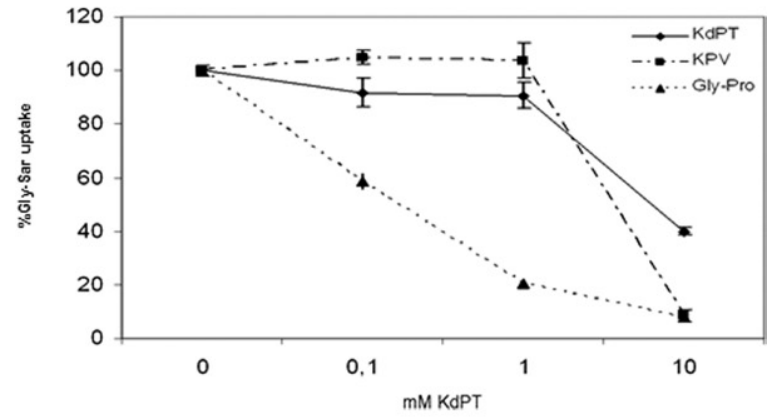

D

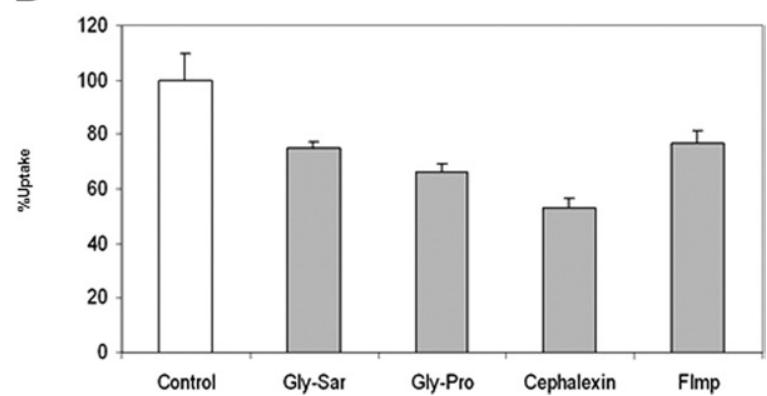

Figure 10. PepT1 mediated transport of KdPT in vitro. A: Caco-2 cells expressing the oligopeptide transporter PepT1 effectively transport the PepT1 substrate Gly-Sar whereas HT-29 cells lack PepT1 expression. In contrast, the transport of radiolabeled KdPT was significantly less effective in Caco-2 cells compared with Gly-Sar, whereas HT-29 cells did not exhibit a significant difference. B: Uptake of Gly-Sar increased from day 4 to day 17, whereas uptake of KdPT significantly dropped. C: Competition assays showed that Gly-Sar uptake was only partially inhibited by high concentrations of KdPT. D: Conversely, excessive amounts of various PepT1 substrates induced a decrease in KdPT uptake in Caco-2 cells. Data are mean \pm SE. All the experiments were performed in triplicate.

less potent than did Gly-Pro or KPV in inhibiting Gly-Sar uptake. Conversely, excess Gly-Sar or Gly-Pro (50 $\mathrm{mmol} / \mathrm{L}$ ) induced a decrease in $\mathrm{KdPT}$ transport across Caco-2 monolayers (Figure 10D).
In in vivo experiments, uptake of Gly-Sar and KdPT was analyzed in control and DSS-treated mice in different intestinal segments (ie, duodenum, jejunum, ileum, and colon) in the presence or absence of large amounts of cold competitive substrates (Figure 11A). The uptake of Gly-Sar followed the PepT1 gradient of protein expression along the digestive tract [mean \pm SE: $(179 \pm 32) \times$ $10^{3} \mathrm{dpm} / \mathrm{g} / 5$ minutes in the duodenum versus $(34 \pm 8) \times$ $10^{3} \mathrm{dpm} / \mathrm{g} / 5$ minutes in the colon]. Moreover, the competitors (Gly-Gly + Gly-Pro) completely blocked Gly-Sar uptake. Gly-Sar uptake was greater than KdPT uptake in all intestinal segments except the colon. In contrast, KdPT uptake was maximal in the distal part of the digestive tract (where PepT1 is absent) compared with other intestinal segments, and the presence of PepT1 competitors did not affect KdPT uptake. DSS treatment did not modify Gly-Sar uptake regardless of the intestinal segment studied (Figure 11B). DSS treatment induced a significant increase in KdPT absorption in the inflamed colon $\left[(20 \pm 2) \times 10^{3} \mathrm{dpm} / \mathrm{g} / 5\right.$
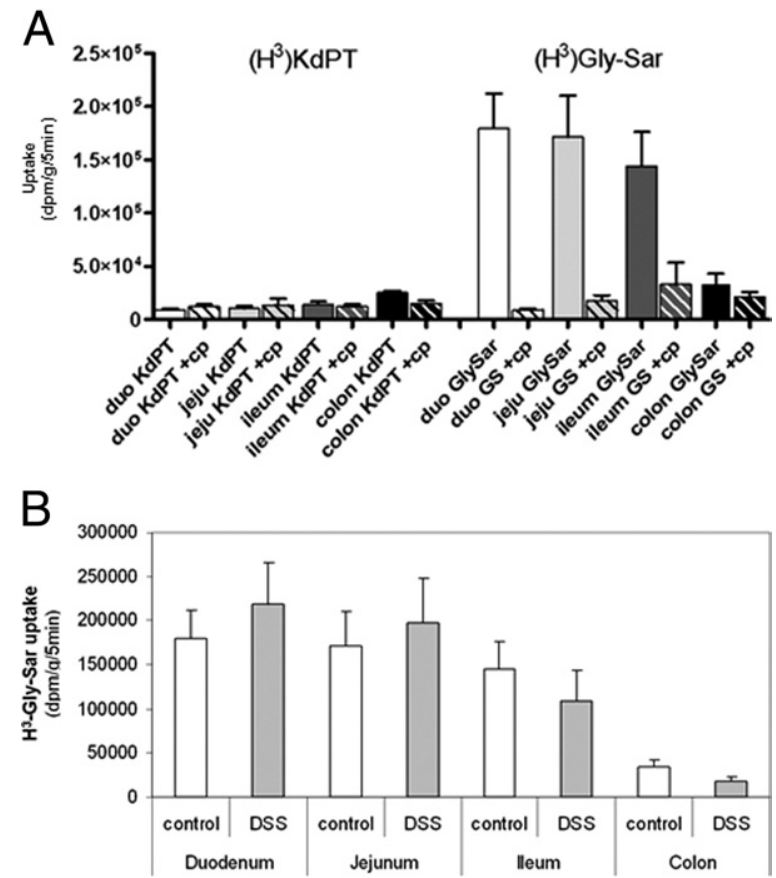

C

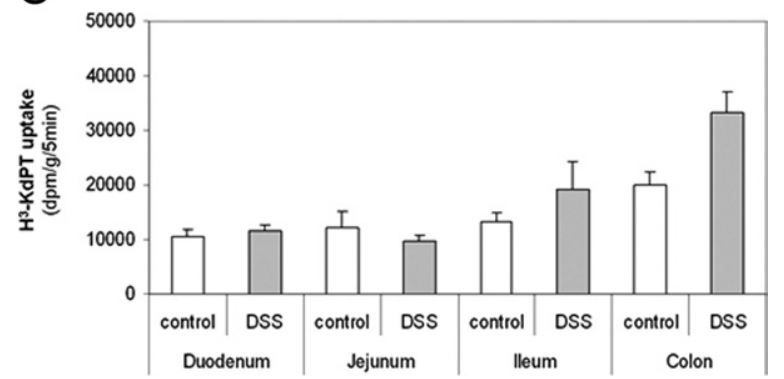

Figure 11. Intestinal uptake of KdPT in vivo. Whereas absorption of KdPT was maximal in the colon (A, left), PepT1-specific Gly-Sar was more effectively absorbed in the small intestinal tract and followed the PepT1 gradient of protein expression (A, right). PepT1 competitors (cp) totally blocked Gly-Sar uptake, whereas KdPT uptake was unaffected (A, hatched bars). DSS treatment did not modify Gly-Sar uptake (B) but induced significantly increased KdPT absorption in the inflamed colon (C). duo, duodenum; jeju, jejunum. 


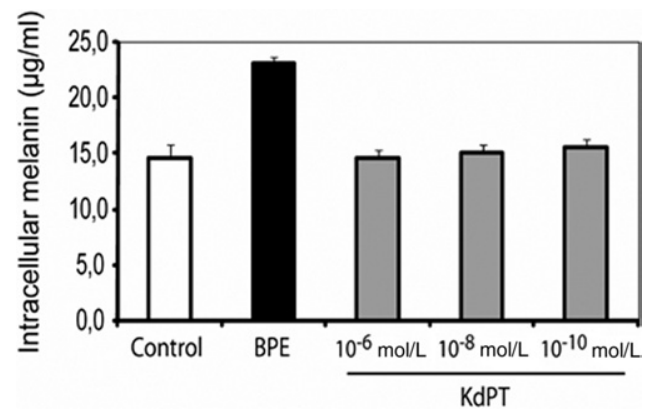

Figure 12. KdPT does not alter melanin synthesis. Normal human melanocytes were exposed to various doses of KdPT for 5 days. Bovine pituitary extracts (BPE) (containing natural melanocortins) were used as positive control. Melanin amounts in the lysed cells were determined photometrically using a synthetic melanin standard. Melanin measurements were performed in triplicate and represent mean $\pm \mathrm{SD}$. Data depict one of three individual experiments with identical results.

minutes versus $(33 \pm 3) \times 10^{3} \mathrm{dpm} / \mathrm{g} / 5$ minutes; $\left.P<0.05\right]$ but did not alter KdPT uptake in the small intestine, suggesting increased availability under inflammatory conditions (Figure 11C). Taken together, these data propose that the uptake of KdPT in vitro and in vivo is transporter mediated but is not solely dependent on the oligopeptide transporter PepT1.

\section{KdPT Does Not Affect Melanin Synthesis in Normal Human Melanocytes}

Although several melanocortin peptides, including $\alpha-\mathrm{MSH}$, have potent immunomodulatory effects in vitro and in vivo, a major disadvantage limiting their clinical use in humans is pigment induction. We, therefore, performed melanin assays of normal human melanocytes exposed to KdPT at various doses. In contrast to bovine pituitary extracts (containing natural melanocortins) and used as a positive control, none of the examined KdPT concentrations led to a significant change in melanin synthesis (Figure 12).

\section{Discussion}

In this study, we demonstrate potent anti-inflammatory efficacy of the MSH-related tripeptide KdPT in two wellestablished models of experimental colitis. Systemic and local administration of KdPT attenuated the course of acute DSS-induced colitis in a concentration-dependent manner, and similar efficacy was demonstrated in IL-10 knockout mice. Furthermore, the compound is able to facilitate the regeneration of epithelial wounds, and it also protects the epithelial barrier by reducing the inflammation-induced breakdown of paracellular permeability in vitro and in vivo.

In light of the melanocortin peptides tested so far, the present results introduce a novel anti-inflammatory agent with future potential for the treatment of IBD. Rajora et $\mathrm{al}^{35}$ originally reported that $\alpha$-MSH reduces colonic inflammation in the DSS model. These authors found decreased colonic expression of TNF- $\alpha$ and nitric oxide after $\alpha-\mathrm{MSH}$ treatment. In support of the anti-inflammatory effect of
$\alpha$-MSH in experimental colitis, it was shown that $\alpha-\mathrm{MSH}$ attenuates trinitrobenzene sulfonic acid-induced colitis. ${ }^{36}$ Recently, Lactobacillus casei-secreting $\alpha$-MSH was also reported to ameliorate DSS-induced colitis, ${ }^{37}$ and we could show that the $\alpha$-MSH fragment KPV has antiinflammatory effects in the DSS and transfer colitis model. ${ }^{13}$ We do not know which of the previously mentioned peptides is most efficient in experimental colitis because direct comparative pharmacologic studies are not yet available. However, preliminary data indicate a more robust inhibition of the murine contact hypersensitivity reaction by KdPT compared with KPV. ${ }^{18}$ In addition, $\mathrm{KdPT}$ does not induce melanogenesis, which represents a significant advantage compared with $\alpha-\mathrm{MSH}$.

Not only pretreatment with KdPT but also therapeutic application after induction of colitis leads to reduced disease activity in DSS-induced colitis. Moreover, the tripeptide also mediates potent therapeutic effects in colitis of IL-10 gene-deficient mice, demonstrating a robust anti-inflammatory capacity regarding intestinal inflammation. Targeted disruption of the IL-10 gene leads to spontaneous development of chronic enterocolitis, with massive infiltration of lymphocytes, activated macrophages, and neutrophils, ${ }^{21,30}$ that is primarily immune mediated but is also dependent on luminal bacteria. In contrast, KdPT does not alter the development of infection with Citrobacter rodentium, an enteropathogenic Escherichia coli infection in mice (data not shown).

Regarding the potential molecular mechanism of KdPT as an anti-inflammatory agent, it has already been speculated that the tripeptide may compete with $\mathrm{IL}-1 \beta$ for binding to the IL-1R. ${ }^{16,17}$ This hypothesis was based on the antagonistic effects of KdPT on IL- $1 \beta$-induced pain in the rat hind-paw assay and on the sequence homology between amino acids 193 to 195 of IL-1 $\beta$ (KPT) and the tripeptide as a stereoisomer. Recent studies investigating the direct antagonistic action of $\mathrm{KdPT}$ and $\mathrm{IL}-1 \beta$ in vitro in fact further suggested an interference of KdPT with IL-1 $\beta$ at the IL-1R type I level. ${ }^{32}$ These studies were performed in vitro and on human cells. Using IL-1R type I-deficient mice, however, we could not find an essential role of the $\mathrm{IL}-1 \mathrm{R}$ type I as a mediator of the in vivo efficacy of KdPT. Accordingly, KdPT exerts its anti-inflammatory and protective actions in chemically induced colitis of mice by alternative mechanisms, eg, by acting on the epithelial barrier.

Because KdPT has structural similarity with the last three amino acids of the C-terminal domain of $\alpha-\mathrm{MSH}$, an interaction with MC-Rs seemed possible a priori. Using $\alpha-\mathrm{MSH}$ radioligand binding assays and the natural $\mathrm{MC}-1 \mathrm{R}$ antagonist Agouti signaling protein, we recently demonstrated that $\mathrm{KdPT}$ does not bind to $\mathrm{MC}-1 \mathrm{R}$ in vitro. ${ }^{32}$ In addition, we investigated whether KdPT has a protective effect on the course of acute DSS-induced colitis in MC-1R signaling-deficient mice. The effect of $\mathrm{KdPT}$ was abolished in the previously mentioned mice strain (see Supplemental Figure S1 at http://ajp. amjpathol.org). Indeed, DSS-induced colitis is aggravated in MC-1R-deficient mice, ${ }^{9}$ possibly reducing the in vivo capacity of $\mathrm{KdPT}$ to control intestinal inflammation. On the other hand, this finding may point to a complex 
role of MC-1R in experimentally induced colitis and the molecular effector mechanism of $\mathrm{KdPT}$, which warrants further investigation.

It has recently been shown that the KdPT-related and truncated $\alpha$-MSH tripeptide KPV is transported via an $\mathrm{H}^{+}$-coupled oligopeptide transporter, PepT1, located at the apical membrane of intestinal epithelial cells. ${ }^{14}$ In this study, nanomolar concentrations of KPV inhibited the activation of $\mathrm{NF}-\kappa \mathrm{B}$ and mitogen-activated protein kinases, thereby reducing proinflammatory cytokine secretion by epithelial cells and by Jurkat T cells. Owing to the structural similarity of KPV and KdPT, it seems likely that the compound is also transported by PepT1; it was, therefore, important to check whether this transporter might be involved in KdPT action on DSS-induced colitis. The present experiments revealed that the presence of competitive and noncompetitive inhibitors of PepT1 reduces the intracellular uptake of KdPT. On the other hand, compared with well-known substrates of PepT1, KdPT is transported less efficiently into Caco-2 cells and in different gastrointestinal segments, suggesting that the efficacy of KdPT is not solely dependent on PepT1 and that other transporters might also be involved. Considering the temperature- and $\mathrm{pH}$-dependent uptake characteristics combined with the saturation kinetics, we assume that PepT1, at least in part, mediates cellular uptake of $\mathrm{KdPT}$. Intriguingly, KdPT uptake in the inflamed colon was significantly higher (50\%), which may reflect upregulation of PepT1 or other transporters in chronically inflamed colons. This might be of substantial advantage in the treatment of IBD with such small anti-inflammatory oligopeptides. ${ }^{14,38,39}$

We further believe that nonspecific, non-receptor-mediated effects of KdPT are rather unlikely for several reasons. First, in vitro data suggest receptor-mediated uptake into epithelial cells. Second, the concentrations of KdPT used in both colitis models are low, and abundant miscellaneous tripeptides are part of the general intestinal contents. Furthermore, a saturating effect of KdPT on intestinal transporters can also be excluded by the present in vitro data, showing that quite high concentrations of KdPT have to be used to inhibit the transport of other peptides specific for PepT1. Finally, we demonstrated that $\mathrm{KdPT}$ is still effective even in the presence of excessive oligopeptides (data not shown).

In the present experiments, the tripeptide stimulated proliferation of intestinal epithelial cells in vivo and in vitro, enhanced closure of mechanically induced wounds of Caco-2 monolayers, attenuated the TNF- $\alpha / \mathrm{IFN}-\gamma$-induced breakdown of TER, and also prevented the redistribution of tight junction proteins in DSS colitis. All of them are readouts of intestinal barrier function. Previous findings could demonstrate that tight junction proteins play a crucial role in experimental and human IBD. ${ }^{31,40}$ Tight junction proteins are internalized by macropinocytosis into colonic epithelial monolayers when incubated with proinflammatory cytokines and in DSS colitis. ${ }^{30}$ In addition, occludin and JAM-A were found to be localized in subapical vesicle-like structures in actively inflamed human ulcerative colitis mucosa. ${ }^{41}$ The present in vitro and in vivo data strongly suggest that KdPT prevents the inflammation-associated changes in tight junction protein distribution, thereby inducing a significantly improved barrier function in experimental colitis.

The present results identifying epithelial integrity as a mechanism of action for MSH-related peptides are supported by a study by Bonfiglio et $\mathrm{al}^{42}$ who showed that KPV facilitated corneal wound healing in rabbits. In addition, it is known that $\alpha-\mathrm{MSH}$ has beneficial effects on gut ischemia injury that may relate to the acceleration of epithelial restitution. ${ }^{32}$ In addition, we did not show a significant alteration in cytokine expression by lamina propria lymphocytes after KdPT treatment in vivo, and significantly higher doses of KdPT were needed to downregulate cytokine expression by RAW macrophages in vitro (data not shown), suggesting that epithelial cells are the primary target of KdPT.

In conclusion, we suggest KdPT to be a new nonmelanotropic and potent anti-inflammatory tripeptide addressing epithelial integrity as a key mechanism involved in the pathogenesis of IBD and, therefore, representing an appealing new therapeutic option for clinical trials in IBD.

\section{Acknowledgments}

We thank Sonja Dufentester, Elke Weber, and Britta Ringelkamp for their expert technical assistance.

\section{References}

1. Bousvaros A, Sylvester F, Kugathasan S, Szigethy E, Fiocchi C, Colletti R, Otley A, Amre D, Ferry G, Czinn SJ, Splawski JB, OlivaHemker M, Hyams JS, Faubion WA, Kirschner BS, Dubinsky MC: Challenges in pediatric inflammatory bowel disease. Inflamm Bowel Dis 2006, 12:885-913

2. Papadakis KA, Targan SR: Role of cytokines in the pathogenesis of inflammatory bowel disease. Annu Rev Med 2000, 51:289-298

3. Hoffmann JC, Preiss JC, Autschbach F, Buhr HJ, Hauser W, Herrlinger K, Hohne W, Koletzko S, Krieglstein CF, Kruis W, Matthes $H$, Moser G, Reinshagen M, Rogler G, Schreiber S, Schreyer AG, Sido B, Siegmund B, Stallmach A, Bokemeyer B, Stange EF, Zeitz M: [Clinical practice guideline on diagnosis and treatment of Crohn's disease] German. Z Gastroenterol 2008, 46:1094-1146

4. Leowardi C, Heuschen G, Kienle P, Heuschen U, Schmidt J: Surgical treatment of severe inflammatory bowel diseases. Dig Dis 2003, 21:54-62

5. Gionchetti P, Rizzello F, Helwig U, Venturi A, Lammers KM, Brigidi P, Vitali B, Poggioli G, Miglioli M, Campieri M: Prophylaxis of pouchitis onset with probiotic therapy: a double-blind, placebo-controlled trial. Gastroenterology 2003, 124:1202-1209

6. Hiltz ME, Lipton JM: Antiinflammatory activity of a $\mathrm{COOH}$-terminal fragment of the neuropeptide $\alpha$-MSH. FASEB J 1989, 3:2282-2284

7. Tatro JB: Receptor biology of the melanocortins, a family of neuroimmunomodulatory peptides. Neuroimmunomodulation 1996, 3:259-284

8. Catania A, Gatti S, Colombo G, Lipton JM: Targeting melanocortin receptors as a novel strategy to control inflammation. Pharmacol Rev 2004, 56:1-29

9. Maaser C, Kannengiesser K, Kucharzik T: Role of the melanocortin system in inflammation. Ann N Y Acad Sci 2006, 1072:123-134

10. Ichiyama T, Sakai T, Catania A, Barsh GS, Furukawa S, Lipton JM: Inhibition of peripheral NF- $\kappa$ B activation by central action of $\alpha$-melanocyte-stimulating hormone. J Neuroimmunol 1999, 99:211-217

11. Lipton JM, Catania A: Anti-inflammatory actions of the neuroimmunomodulator $\alpha$-MSH. Immunol Today 1997, 18:140-145

12. Brzoska T, Luger TA, Maaser C, Abels C, Bohm M: $\alpha$-Melanocytestimulating hormone and related tripeptides: biochemistry, antiinflammatory and protective effects in vitro and in vivo, and future perspec- 
tives for the treatment of immune-mediated inflammatory diseases. Endocr Rev 2008, 29:581-602

13. Kannengiesser $\mathrm{K}$, Maaser $\mathrm{C}$, Heidemann J, Luegering A, Ross M, Brzoska T, Bohm M, Luger TA, Domschke W, Kucharzik T: Melanocortin-derived tripeptide KPV has anti-inflammatory potential in murine models of inflammatory bowel disease. Inflamm Bowel Dis 2008, 14:324-331

14. Dalmasso G, Charrier-Hisamuddin L, Nguyen HT, Yan Y, Sitaraman S, Merlin D: PepT1-mediated tripeptide KPV uptake reduces intestinal inflammation. Gastroenterology 2008, 134:166-178

15. Ferreira SH, Lorenzetti BB, Bristow AF, Poole S: Interleukin- $1 \beta$ as a potent hyperalgesic agent antagonized by a tripeptide analogue. Nature 1988, 334:698-700

16. Follenfant RL, Nakamura-Craig M, Henderson B, Higgs GA: Inhibition by neuropeptides of interleukin- $\beta$-induced, prostaglandin-independent hyperalgesia. Br J Pharmacol 1989, 98:41-43

17. Mugridge KG, Perretti M, Ghiara P, Parente L: $\alpha$-Melanocyte-stimulating hormone reduces interleukin- $1 \beta$ effects on rat stomach preparations possibly through interference with a type I receptor. Eur J Pharmacol 1991, 197:151-155

18. Luger TA, Brzoska T: $\alpha$-MSH related peptides: a new class of antiinflammatory and immunomodulating drugs. Ann Rheum Dis 2007, 66(Suppl 3):iii52-iii55

19. Maaser C, Kannengiesser K, Specht C, Lugering A, Brzoska T, Luger TA, Domschke W, Kucharzik T: Crucial role of the melanocortin receptor MC1R in experimental colitis. Gut 2006, 55:1415-1422

20. Berg DJ, Zhang J, Weinstock JV, Ismail HF, Earle KA, Alila H, Pamukcu R, Moore S, Lynch RG: Rapid development of colitis in NSAIDtreated IL-10-deficient mice. Gastroenterology 2002, 123:1527-1542

21. Kuhn R, Lohler J, Rennick D, Rajewsky K, Muller W: Interleukin-10deficient mice develop chronic enterocolitis. Cell 1993, 75:263-274

22. Blum AM, Metwali A, Elliott DE, Berg DJ, Weinstock JV: CD4+ T cells from IL-10-deficient mice transfer susceptibility to NSAID-induced Rag colitis. Am J Physiol Gastrointest Liver Physiol 2004, 287:G320G325

23. de Silva HJ, Gatter KC, Millard PR, Kettlewell M, Mortensen NJ, Jewell DP: Crypt cell proliferation and HLA-DR expression in pelvic ileal pouches. J Clin Pathol 1990, 43:824-828

24. Lostao MP, Urdaneta E, Martinez-Anso E, Barber A, Martinez JA: Presence of leptin receptors in rat small intestine and leptin effect on sugar absorption. FEBS Lett 1998, 423:302-306

25. Burk RR: A factor from a transformed cell line that affects cell migration, Proc Natl Acad Sci U S A 1973, 70:369-372

26. Bruewer M, Luegering A, Kucharzik T, Parkos CA, Madara JL, Hopkins AM, Nusrat A: Proinflammatory cytokines disrupt epithelial barrier function by apoptosis-independent mechanisms. J Immuno 2003, 171:6164-6172

27. Kitajima S, Takuma S, Morimoto M: Changes in colonic mucosa permeability in mouse colitis induced with dextran sulfate sodium. Exp Anim 1999, 48:137-143

28. Ukena SN, Singh A, Dringenberg U, Engelhardt R, Seidler U, Hansen W, Bleich A, Bruder D, Franzke A, Rogler G, Suerbaum S, Buer J,
Gunzer F, Westendorf AM: Probiotic Escherichia coli Nissle 1917 inhibits leaky gut by enhancing mucosal integrity. PLoS One 2007, 2:e1308

29. Dieleman LA, Palmen MJ, Akol H, Bloemena E, Pena AS, Meuwissen SG, Van Rees EP: Chronic experimental colitis induced by dextran sulphate sodium (DSS) is characterized by Th1 and Th2 cytokines. Clin Exp Immunol 1998, 114:385-391

30. Berg DJ, Davidson N, Kuhn R, Muller W, Menon S, Holland G, Thompson-Snipes L, Leach MW, Rennick D: Enterocolitis and colon cancer in interleukin-10-deficient mice are associated with aberrant cytokine production and CD4(+) TH1-like responses. J Clin Invest 1996, 98:1010-1020

31. Mennigen R, Nolte K, Rijcken E, Utech M, Loeffler B, Senninger N, Bruewer M: Probiotic mixture VSL\#3 protects the epithelial barrier by maintaining tight junction protein expression and preventing apoptosis in a murine model of colitis. Am J Physiol Gastrointest Liver Physio 2009, 296:G1140-1149

32. Mastrofrancesco A, Kokot A, Eberle A, Gibbons NC, Schallreuter KU, Strozyk E, Picardo M, Zouboulis CC, Luger TA, Bohm M: KdPT, a tripeptide derivative of $\alpha$-melanocyte-stimulating hormone, suppresses IL-1 $\beta$-mediated cytokine expression and signaling in human sebocytes. J Immunol 2010, 185:1903-1911

33. Gonzalez-Navajas JM, Law J, Nguyen KP, Bhargava M, Corr MP, Varki N, Eckmann L, Hoffman HM, Lee J, Raz E: Interleukin 1 receptor signaling regulates DUBA expression and facilitates Toll-like receptor 9-driven antiinflammatory cytokine production. J Exp Med 2010, 207 2799-2807

34. Adibi SA: The oligopeptide transporter (Pept-1) in human intestine: biology and function. Gastroenterology 1997, 113:332-340

35. Rajora N, Boccoli G, Catania A, Lipton JM: $\alpha-\mathrm{MSH}$ modulates experimental inflammatory bowel disease. Peptides 1997, 18:381-385

36. Oktar BK, Ercan F, Yegen BC, Alican I: The effect of $\alpha$-melanocyte stimulating hormone on colonic inflammation in the rat. Peptides 2000, 21:1271-1277

37. Yoon SW, Lee CH, Kim JY, Kim JY, Sung MH, Poo H: Lactobacillus casei secreting $\alpha-\mathrm{MSH}$ induces the therapeutic effect on DSS-induced acute colitis in Balb/c mice. J Microbiol Biotechnol 2008, 18:1975-1983

38. Bai JP, Amidon GL: Structural specificity of mucosal-cell transport and metabolism of peptide drugs: implication for oral peptide drug delivery. Pharm Res 1992, 9:969-978

39. Thwaites DT, Cavet M, Hirst BH, Simmons NL: Angiotensin-converting enzyme (ACE) inhibitor transport in human intestinal epithelia (Caco-2) cells. Br J Pharmacol 1995, 114:981-986

40. Laukoetter MG, Nava P, Nusrat A: Role of the intestinal barrier in inflammatory bowel disease. World J Gastroenterol 2008, 14:401-407

41. Bruewer M, Utech M, Ivanov Al, Hopkins AM, Parkos CA, Nusrat A: Interferon- $\gamma$ induces internalization of epithelial tight junction proteins via a macropinocytosis-like process. FASEB J 2005, 19:923-933

42. Bonfiglio V, Camillieri G, Avitabile T, Leggio GM, Drago F: Effects of the $\mathrm{COOH}$-terminal tripeptide $\alpha$-MSH(11-13) on corneal epithelia wound healing: role of nitric oxide. Exp Eye Res 2006, 83:1366-1372 